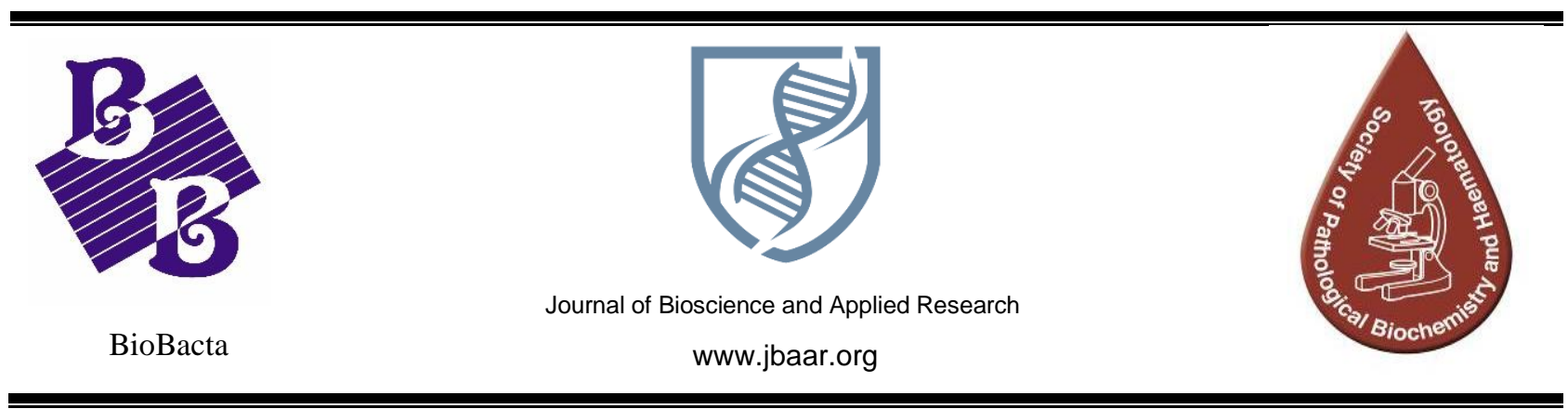

\title{
Towards Sustainable Management of E-Waste in the Kingdom of Saudi Arabia: A Comparative Study of Three International Models
}

\author{
Asma Abdullah Ahmad Filimban', Furat Ahmed Mahmood Al-Faraj², Akponanabofa Henry Oti ${ }^{2}$ \\ ${ }^{1}$ General Authority of Meteorology and Environmental Protection, Saudi Arabia. \\ ${ }^{2}$ School of Engineering, University of Bolton, United Kingdom \\ (Corresponding Author: Dr Furat Al-Faraj, Email: f.al-faraj@bolton.ac.uk) \\ DOI: 10.21608/jbaar.2019.147394
}

\begin{abstract}
Waste produced from the end of useful life electrical and electronic equipment (EEE) denoted as e-waste, is one of the fastest waste streams worldwide. The growing amount of e-waste has caused a considerable challenge for policymakers to manage e-waste in an environmentally-sound mode in both developed and developing countries. Effective management of e-waste has become a global concern that is receiving growing attention due to the rapid increase in the quantity of e-waste. This is mainly attributed to the rapid technological innovation and shortening product's useful lifespan coupled with the tendency of people to keep up with the advanced technologies. This study compared and critically appraised three e-waste management models (producer responsibility, not-producer responsibility, and sharing responsibility) currently applied in Malaysia and the United States of America (USA), in an attempt to explore best management practices for the collection and treatment of e-waste that can be adopted in the Kingdom of Saudi Arabia. The data presented in this paper are secondary data obtained from a wide range of authoritative sources. This study recommends developing an e-waste national policy and regulatory framework to effectively manage the rapidly growing rate of e-waste in the Kingdom of Saudi Arabia.
\end{abstract}

Keywords: E-waste production; E-waste management; E-waste recycling; Hazardous substance; Basel Convention; Recycling fee responsibility

\section{Introduction}

Advancement in technology is continuously influencing the lifestyle of the world's rising population. The demand for using new EEE is increasing while the useful life of these becomes Received date: May 8, 2019. Accepted: July 20, 2019, Published: July 29, 2019 shorter. Widmer et al. (2005) reported that the average lifespan of a new model computer has dropped from approximately five years in 1992 to about two years in 2005. They also stated that cell phones start to malfunction after 2 to 3 years of use 
compelling users to change to the latest version of the product incessantly. This suggests that e-waste has become one of the fastest streams of municipal solid waste generated (Dashkova, 2012). According to the United Nations University, the estimated volume of electronic waste produced in 2016 is about 43 million tons, which is approximately $8 \%$ higher compared to 2014. Europeans produce $20 \mathrm{~kg}$ of e-waste per person each year, while USA inhabitants generate about $7 \mathrm{~kg}$ of e-waste per person per year (Namias, 2013). Ewaste composition is different from one country to another. E-waste usually consists of a mixture of hazardous and valuable components, which are considered the most complex type of municipal waste generated continuously (Edwards, 2016). The management of e-waste is even more complex with the need for recycling and sustainable disposal of hazardous components. It is more critical in countries where there are fewer industries that manufacture EEE but use a wide range of products spanning different development ages imported over time. It is therefore important to survey the best international practices, especially in nations that carry out both the manufacturing and the effective management of EEE, to be adopted in developing countries that lack the strengths of effective and efficient management of ewaste. This paper appraised the e-waste management practices currently applied in Malaysia and four states of the USA, in an attempt to extract some potential measures and suggest some recommendations to effectively manage the e-waste in the KSA.

\section{Background and progress in e-waste management}

\subsection{The nature of e-waste and implications on health}

E-waste is considered substantially hazardous if managed irresponsibly and incorrectly. Inappropriate management of e-waste hurts the environment and can threaten human health. E-waste largely comprises heterogeneous components, some of them are valuable materials while others contain toxic substances that can contaminate environmental media (water, air, and soil) and cause serious health problems (Vennila et al., 2014; UNESCO, 2017; Lang, 2018; Erin, 2019).

Routes of exposure and concentration of substances can therefore vary as suggested by Grant et al (2013) in Table 1.

Researchers (Dashkova, 2012) have noted cases of sending e-waste to the landfill without appropriate treatment. The danger with such an act is that heavy metals and other hazardous substances could be introduced to the soil and eventually to aquifers or other water reservoirs through leaching. Reclaiming resulting in contaminated soil and water reservoirs can be expensive. Also, incinerating e-waste can release harmful gases that affect air quality (Dashkova, 2012). Guiyu, Hong Kong is a clear example of how e-waste is harmful to the environment and human health. Guiyu, Hong Kong is considered the largest site for e-waste dumping in the world (Watson, 2013). China appears to be the highest e-waste dump (e-waste basket) in the world. The United Nations banned e-waste transportation between countries but developed countries still export their e-waste to less privileged countries such as China and Vietnam illegally (Watson, 2013). Unsafe e-waste recycling and reuse can lead to discharges such as acids and sludge, which contaminate water sources. 
Table 1: E-waste chemical components and electronic equipment, sources and routes of exposure (Grant et al., 2013; Ramachandra and Varghese, 2004)

\begin{tabular}{|c|c|c|c|c|}
\hline Element & $\begin{array}{l}\text { Component of electrical and } \\
\text { electronic equipment }\end{array}$ & $\begin{array}{l}\text { Ecological } \\
\text { source of } \\
\text { exposure } \\
\end{array}$ & $\begin{array}{l}\text { Route of } \\
\text { exposure }\end{array}$ & Health implications \\
\hline Lead & $\begin{array}{l}\text { Printed circuit boards, cathode } \\
\text { ray tubes, light bulbs, } \\
\text { televisions }(1 \cdot 5-2 \cdot 0 \mathrm{~kg} \text { per } \\
\text { monitor), and batteries }\end{array}$ & $\begin{array}{l}\text { Air, dust, water, } \\
\text { and soil }\end{array}$ & $\begin{array}{l}\text { Inhalation, } \\
\text { ingestion, and } \\
\text { dermal contact }\end{array}$ & $\begin{array}{l}\text { Toxic to the brain and } \\
\text { nervous systems } \\
\text { Can lead to coma or death }\end{array}$ \\
\hline Chromium & $\begin{array}{l}\text { Anticorrosion coatings, data } \\
\text { tapes, and floppy disks }\end{array}$ & $\begin{array}{l}\text { Air, dust, water, } \\
\text { and soil }\end{array}$ & $\begin{array}{l}\text { Inhalation and } \\
\text { ingestion }\end{array}$ & $\begin{array}{l}\text { Asthmatic bronchitis. } \\
\text { DNA damage }\end{array}$ \\
\hline Cadmium & $\begin{array}{l}\text { Switches, springs, connectors, } \\
\text { printed circuit boards, } \\
\text { batteries, infrared detectors, } \\
\text { semi-conductor chips, ink or } \\
\text { toner photocopying machines, } \\
\text { cathode ray tubes, and mobile } \\
\text { phones }\end{array}$ & $\begin{array}{l}\text { Air, dust, soil, } \\
\text { water, and food } \\
\text { (especially rice } \\
\text { and vegetables) }\end{array}$ & $\begin{array}{l}\text { Ingestion and } \\
\text { inhalation }\end{array}$ & $\begin{array}{l}\text { Toxic irreversible effects } \\
\text { on human health. } \\
\text { Teratogenic } \\
\text { Accumulates in the kidney } \\
\text { and liver. } \\
\text { Causes neural damage. }\end{array}$ \\
\hline Mercury & $\begin{array}{l}\text { Thermostats, sensors, } \\
\text { monitors, cells, printed circuit } \\
\text { boards, and cold cathode } \\
\text { fluorescent lamps ( } 1-2 \mathrm{~g} \text { per } \\
\text { device) }\end{array}$ & $\begin{array}{l}\text { Air, vapour, } \\
\text { water, soil, and } \\
\text { food (bio } \\
\text { accumulative in } \\
\text { fish) }\end{array}$ & $\begin{array}{l}\text { Inhalation, } \\
\text { ingestion, and } \\
\text { dermal contact }\end{array}$ & $\begin{array}{l}\text { Chronic damage to the } \\
\text { brain. } \\
\text { Respiratory and skin } \\
\text { disorders due to } \\
\text { bioaccumulation in fishes. }\end{array}$ \\
\hline Zinc & $\begin{array}{l}\text { Cathode ray tubes, and metal } \\
\text { coatings }\end{array}$ & $\begin{array}{l}\text { Air, water, and } \\
\text { soil }\end{array}$ & $\begin{array}{l}\text { Ingestion and } \\
\text { inhalation }\end{array}$ & $\begin{array}{l}\text { Cause of nausea, diarrhoea } \\
\text { or vomiting }\end{array}$ \\
\hline Nickel & Batteries & $\begin{array}{l}\text { Air, soil, water, } \\
\text { and food } \\
\text { (plants) }\end{array}$ & $\begin{array}{l}\text { Inhalation, } \\
\text { ingestion, } \\
\text { dermal contact, } \\
\text { and } \\
\text { transplacental. }\end{array}$ & $\begin{array}{l}\text { Carcinogenic to lungs } \\
\text { Cardiovascular disease } \\
\text { Neurological defects } \\
\text { High blood pressure }\end{array}$ \\
\hline
\end{tabular}

\subsection{Management of e-waste}

The hierarchy of e-waste management strategy (Figure 1) presents the ordering of waste management solutions from the most effective options to the least one. The five options of this general waste hierarchy are further explained in Table 2. Note that the ranking of waste management options may differ in a hierarchy in different countries. Most countries promote the three middle options in the hierarchy (re-use, recycle, and recovery), but some countries in the EU region are starting to adopt this general structure of waste management (avoidance/prevention) (Hamzah, 2011). 


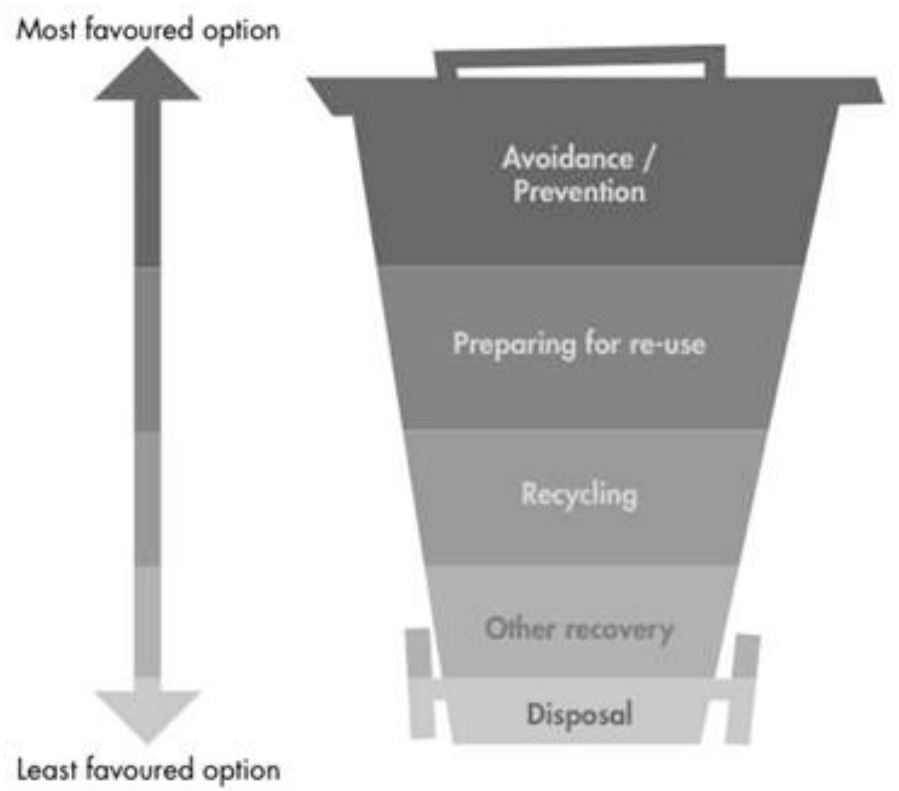

- Designing out waste
- Maximise product lifetime
- Hiring over buying new
- Using less hazardous materials

Checking, cleaning, repairing, refurbishing, whole items or spare parts

Turning waste into a new product. Includes composting if it meets quality protocols

Includes incineration with energy recovery, gasification and pyrolysis which produce energy

landfill and incineration without energy recovery

Figure 1: Waste Hierarchy Management (Laird, 2012).

Table 2: Waste Hierarchy Ranking and Description (Hamzah, 2011).

\begin{tabular}{|l|l|}
\hline Option & Explanation \\
\hline $\begin{array}{l}\text { Avoidance/ } \\
\text { Prevention }\end{array}$ & $\begin{array}{l}\text { Stay away from producing waste by reducing the volume of waste } \\
\text { Design the equipment with less hazardous materials } \\
\text { Increase the lifespan of the products }\end{array}$ \\
\hline Re-use & $\begin{array}{l}\text { Prepare the waste for reuse again (cleaning, repairing, and } \\
\text { refurbishing), which will extend the lifetime of the item. }\end{array}$ \\
\hline Recycling & $\begin{array}{l}\text { Transferring the waste into a new item, which reduces the amount of } \\
\text { waste and conserves the resources at the same time. }\end{array}$ \\
\hline Recovery & $\begin{array}{l}\text { It can be by "incineration with energy recovery, gasification, and } \\
\text { pyrolysis which produce energy". }\end{array}$ \\
\hline Disposal & $\begin{array}{l}\text { It is the last favourite option, which should be used when the waste } \\
\text { cannot be recycled and the residual material after all previous options. }\end{array}$ \\
\hline
\end{tabular}

Another important aspect of e-waste management is the processing of the waste or scrap, common to all the management options. There are three main stages of managing the e-scrap: collection, sorting, and end processing (Namias, 2013). The first stage, Collection, may cover regional or national range. It is accomplished through recovery programs sponsored by the retail traders and manufacturers of electronics. Examples include municipal drop-off collection points, which could be non-profit and for-profit collection programs. This usually results in large heaps of e-waste, which need sorting. The second stage is sorting which can be done both locally and nationally at different scales based on objectives. Processes may include further separation activities through magnetization, shredding materials, and the eventual segregation into material streams of metals, glass, and plastics. This stage may combine manual efforts and mechanical processes (Table 3) and helps to accomplish the separation of valuable components and the removal/safe disposal of hazardous items/substances. The end processing has some general application globally which entails the recovery of precious components and cleaning them from any pollution. 
Table 3: E-waste management process (Namias, 2013).

\begin{tabular}{|l|l|l|l|}
\hline Stage & Stream & Process & Level \\
\hline Collection & Equipment's & Manually & Regional or National \\
\hline $\begin{array}{l}\text { Sorting/dismantling and } \\
\text { mechanical processing }\end{array}$ & Equipment's & $\begin{array}{l}\text { Manually and } \\
\text { Mechanical }\end{array}$ & Regional or National \\
\hline End-processing & Material & Chemical & Global \\
\hline
\end{tabular}

\subsection{Global scenes in e-waste management}

The technology boom has continued to influence lifestyle changes. The demand for electronic and electrical equipment has therefore increased. Thus, resulting in an increase in the amount of electronic waste especially with the decrease in the life span of the equipment. The Global E-waste Monitor (2017), estimated the e-waste amount produced in 2016 at about 44.7 million metric tons and is projected to be 52.2 metric tons in 2021. However, most e-waste ended up in landfills, incinerated, or recycled under non-standard conditions (Balde et al., 2017). According to Balde et al (2017), the growth in ewaste can be attributed to:

- More people using the internet and online businesses from expanding internet access networks with faster broadband and wider coverage. According to Global E-waste Monitor (2017), almost half of the world's population are online using the internet. Also, 4.2 billion people have active mobilesubscriptions broadband globally. While about $54 \%$ of households have internet access at home and $48 \%$ own a computer.

- The electrical and electronic equipment in the global market is increasing continuously, but appliance useful lifespan is decreasing. The lifespan of computers has dropped down from six years in 1997 to only two years in 2005 and the average lifecycle of phones is less than two years. This compels the consumer to change and buy a new product continually.

- Many people own more than one connected appliance including phones, laptops, and ereaders. In the USA, it is suggested that everyone owns a phone.

- Consumers buy a new product to own the latest version to keep up with technological advancements.

\section{Research Design and Methodology}

The method used in this research follows a comparative case studies-based approach. The analysis of a set of international case studies enables the critical appraisal of some international practices on sustainable management of e-waste and identify best practices that could be applied in developing countries such as the Kingdom of Saudi Arabia. Three case studies (models) were examined. Model 1: producer responsibility (California State); Model 2: not-producer responsibility (Washington, Oregon, and New York); and Model 3: sharing responsibility (Malaysia). The research methodology is schematized in Figure 2. The analysis is divided into three phases. Phase 1: comparison between Model 1 and Model 2; Phase 2: comparison between Model 2 and Model 3; and Phase 3: comparison between Model 1 and Model 3. Best practices and procedures extracted from the comparison between the three models are used to propose some measures to effectively and efficiently manage e-waste in the Kingdom of Saudi Arabia. 


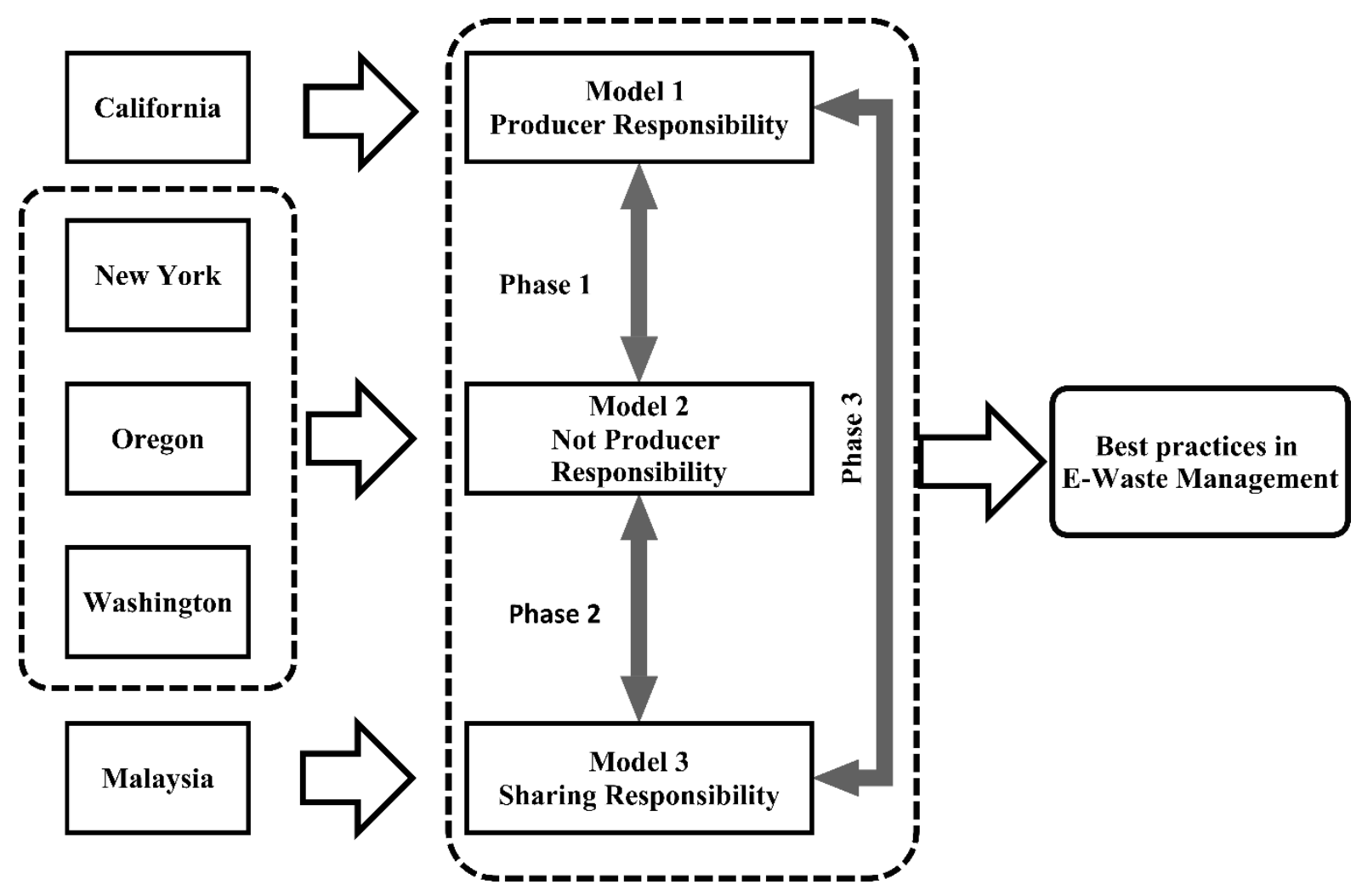

Figure 2. Research Approach

\section{$4 \quad$ Research implementation}

\subsection{E-Waste Management in Saudi Arabia}

The Chemical Safety and Hazardous Wastes department at the General Authority of Meteorology and Environment Protection is responsible for taking care of E-waste management in Saudi Arabia. The kingdom generates 378,000 tons of e-waste every year (Alameer, 2015). Saudi Arabia produced the highest amount of e-waste among Gulf Cooperation Council (GCC) Countries as indicated in Figure 3 (Alghozo and Ouda, 2016). The Gulf Cooperation
Council countries are Bahrain, Kuwait, Oman, Qatar, Saudi Arabia, and the United Arab Emirates.

Saudi Arabia generates an enormous amount of ewaste and most of them end up in a landfill. This creates a lot of environmental challenges in the country (Alameer, 2015) which constitute a cause for concern. The e-recycling rate $(10-15 \%)$ is too low compared to the generated amount. Also, the recycling process is largely carried out by the informal sector and there are limited records that it is being done in the right way (Alghozo and Ouda, 2016). 


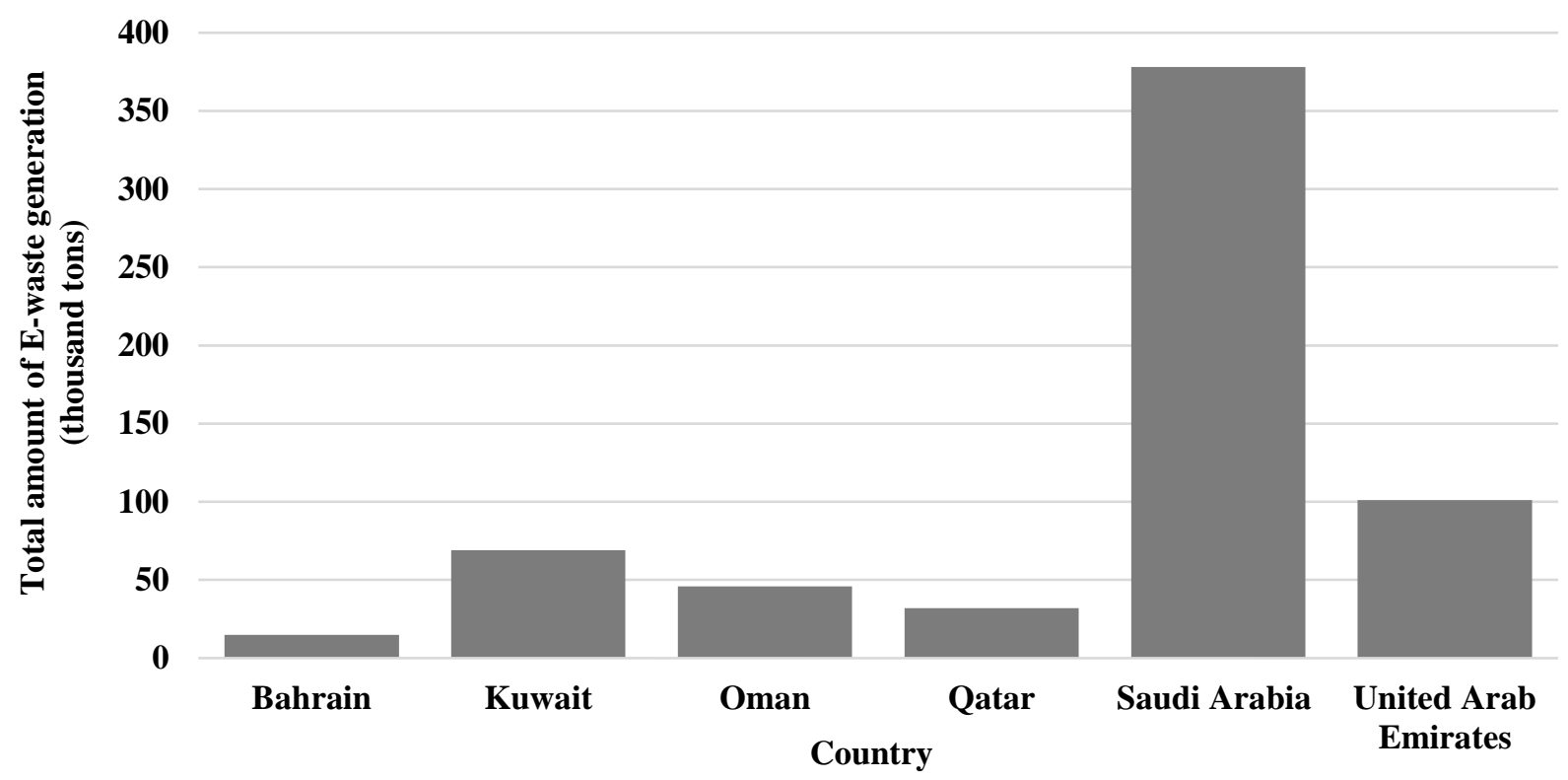

Figure 3: Total amount of e-waste generation in GCC countries in 2014 (Alghozo and Ouda, 2016).

According to Alameer (2015), there are no clear regulations on e-waste management in Saudi Arabia, but the country is starting to realize the need to tackle the challenge by taking appropriate actions towards adopting a sustainable e-waste management approach. The major challenges are that there is no proper method for e-waste handling (collection and transporting) and there is a very low public awareness about e-waste recycling (Alameer, 2015).

\subsubsection{E-waste management in the USA}

The USA ranked the second highest in producing ewaste after China (Richter, 2017). E-waste is suggested to be the fastest-growing stream of municipal waste in the USA because of people buying new versions of technology gadgets (Shumon et al., 2014). The US Environmental Protection Agency (EPA) states that around $80 \%$ to $85 \%$ of the end life of electronic goes to landfills (Shumon et al., 2014).

Although the recycling rate for e-scrap appears to be increasing, a good proportion of the e-waste end up in landfill more than are recycled in the USA. Only $40 \%$ of e-waste generated in 2013 was recovered for recycling outside of the country, while the majority was trashed (landfill or incineration). That means $40 \%$ was exported, which is a considerable amount
(Electronics TakeBack Coalition, 2019; EPA, 2019a). Note that about $25.3 \%$ of e-waste in the world was generated by the USA in 2016 (Balde et al., 2017). The main dumping site for US e-waste is Guiyu, China (Button, 2016).

Balde et al. (2017) reported that the United States of America (USA) still does not have a nation-wide ewaste management legislation, and instead has state regulations to manage e-waste. However, in the USA, measures such as the Resource Conservation and Recovery Act (RCRA), were put in place, to prevent e-waste and to limit the negative effects posed by unappropriated disposal and treatment. Recently, placing electronics in the trash is illegal for most US companies, and the disposal of electronics into municipal waste streams has been banned in some states (Namias, 2013). The first state to enact e-waste recycling legislation, the Electronic Waste Recycling Act, is California in 2003. This legislation is inclusive of a broader waste ban and advances retrieval fee funding. Also, e-waste cannot be disposed of in landfills or sent overseas (American Recycler News Inc., 2017). 
(a) E-waste management in California

To attend to e-waste issues, the Electronic Waste Recycling Act of 2003 was ratified in September 2003 in California as the first e-waste recycling legislation in the United States (Bergner, 2004). The Electronic Waste Recycling Act of 2003 aims to decrease and minimize the use of perilous elements such as cadmium, lead, mercury, and nickel in electronic devices that are sold in California (Namias, 2013). Also, consumers who purchase some kinds of electronic equipment that contains cathode ray tubes (CRT), liquid crystal display (LCD), and plasma display devices, have been mandated to pay the waste recycling fee. The fee is collected by retailers who have the right to keep 3\% of the amount to cover the costs of collection (Namias, 2013).

\section{(b) E-waste management in Washington}

The e-recycle program of Washington was established in 2006 (NCSL, 2018), to supply the residents with free e-waste recycling. Under this program, electronic manufacturers are responsible to offer an e-recycling option to the customers at no additional cost. That means the companies that manufacture electronic devices are paid the recycling fee. After three years of commencing the program, the state began to recycle TVs, computers, and monitors. By 2013, tablet computers, e-readers, and portable DVD players were added to the list.

\section{(c) E-waste management in Oregon}

In 2007, Oregon's Electronics Recycling Law established the Oregon E-Cycles (NCSL, 2018). Oregon E-Cycles provides collection sites that accept up to seven electronic items at one time free of charge from households and small businesses. On the other hand, large businesses are required to pay recycling fees. However, Oregon E-Cycles does not offer free e-recycling for all electronic devices. Oregon prohibited the disposal of all computers, monitors, and TVs as of 2010. (d) E-waste management in New York

To ensure e-waste in New York is recycled appropriately, the New York State (NYS) Electronic Equipment Recycling and Reuse Act was established on May 28, 2010 (Department of Environmental Conservation, 2019). The act demands e-industrialist to provide electronic consumers (for residents and small businesses) with free recycling of their expired devices. While profit businesses with 50 or more fulltime employees might need to pay the recycling fee and not-for-profit corporations with 75 or more fulltime employees may be charged as well. According to NYS E-waste Recycling and Reuse Act report (2017), about 420 million pounds of e-waste from New York consumers were recycled or reused appropriately from April 2011 to December 2015. Furthermore, it is considered the most comprehensive and advanced e-waste legislation in the country (Department of Environmental Conservation, 2017). Also, the study by Williams (2018) suggests that the current e-waste stream has reduced from about $60 \%$ to $27 \%$ in New York compared to 2005 quantities.

\subsubsection{E-waste in Malaysia}

Malaysia is classed as a developing economy. The country has been interested in environmental acts and regulations since 1974 because of the attention on pollution from their early exploitation by palm oil mill and rubber mill industries. As time went on the concern extended to other sources of pollution as the country continued to develop through further industrialization, technology boom, and population growth. The environmental quality in Malaysia became a cause for concern (Isa, 2012). Although by the end of the 2010 decade, Malaysia is forecast to grow into the developed countries category, the need to combat e-waste is one primary aspect to overcome. The demand for using electronic equipment is increasing with the growth in the economy and urbanization in the country (Zainu et al., 2015).

Semarang (2016) stated that the estimated amount of e-waste generated in Malaysia in 2020 will be 53 million pieces, 3.5 times more than 1995 quantities. Note that the study looked at 6 devices: TVs, PCs, 
mobile phones, refrigerators, air conditions, and washing machines (Semarang, 2016). However, due to the significant amount of increasing e-waste, the study concentrated on the most challenging types of hazardous waste in the country (Zainu et al., 2015). The current suggestion is that the e-waste management program in Malaysia should be developed as one of the vision 2020 objectives. That means Malaysia will not only be promoting economic and social aspects, but also the environmental aspects with regards to e-waste management (UKEssay, 2018). At the moment, e-waste management in Malaysia is mainly handled by private businesses with little government input. There also exist some ewaste recycling voluntary activities (Zainu et al., 2015). According to Hamzah (2011), Malaysia is one of the few countries that receive e-waste from the USA. However, less developed countries such as India import e-waste from Malaysia. UKEssays (2018) reported that most of the e-waste in Malaysia end up in landfill due to absence of or inadequate collection and disposal mechanism. Without a proper management system, particularly in disposal processes, hazardous substances contained in e-waste can cause adverse effects to the surrounding environment and human health (Forti et al., 2018). An overview of current e-waste management in Malaysia (Masrom, 2017) indicates that it is a shared responsibility. Recycling cost is shared between stakeholders, which means all e-waste stakeholders have to pay the recycling fee including companies that manufacture the devices, consumers, collectors, and recyclers (Asian Region, 2014). According to the Asian Network Workshop (2017), the Japan International Cooperation Agency (JICA) technical cooperation in DOE is developing a project for a new e-waste management mechanism. This project aims to apply sustainable and environmentally sound ewaste management (collection and recycling) strategy (Masrom, 2017). The DOE issued 146 ewaste recovery facilities licenses in total; 18 of them are full recovery facilities while 128 is for partial recovery (Suja et al., 2014).
The Malaysian government established a hazardous waste regulation in 1989. This was due to hazardous waste becoming a major issue in 1985s. To control the illegal hazardous waste movement, Malaysia joined the Basel Convention in October 1993 (Isa, 2012). Malaysia has established a strict law on hazardous waste movement. The restriction is that no one can dispose of, receive, and send e-waste in or out of Malaysia without any prior written approval of the Director-General under the Basel Convention. If the law is violated, punishment includes the payment of RM 500,000 (equivalent to about 120,000 USD based on the 16th June 2019 currency exchange rate) or spend no more than five years in prison (Isa, 2012). Also, the Royal Customs Department and Department of Environment is responsible for the control of hazardous waste movement at the entry point into the country. A consignment note is one of the instruments used to detect illegal hazardous waste dumping. The hazardous waste movement also monitors Malaysia for generators, transporters, and receivers of the waste movement. Furthermore, the government imposed all hazardous wastes handlers to use electronic-consignment notes through web base applications (Isa, 2012).

Never the less Malaysia still have challenges to resolve in e-waste management. These are described as follows.

- Due to the geographical location of Malaysia (middle of international e-waste trade), she plays a key role in e-waste trading - as an importer and exporter and constitutes an international e-waste route movement that perpetrators use (Hamzah, 2011).

- There is no appropriate system of segregation and disposal of e-waste to encourage the enforcement of the public in recycling and appropriate discarding of ewaste (UKEssays, 2018).

- Inadequate infrastructure for e-waste management (UKEssays, 2018).

- The low economy of the country creates an informal sector and illegal e-waste recycling, 
which is due to the scrambling for valuable e-waste components (Hamzah, 2011).

\subsection{Findings and discussion from comparison}

4.2.1 Phase 1 - comparison of models 1 and 2

(a) Scope of products covered
There are 7 categories of products covered in models 1 and 2 (Table 4). Although California commences erecycle first New York covered more products than others. This confirms that New York has the most comprehensive and progressive e-waste program in the USA (Department of Environmental Conservation, 2017).

Table 4: Products covered in models of e-waste management

\begin{tabular}{|c|c|c|c|c|c|c|}
\hline \multirow[b]{2}{*}{ S/No } & \multirow[b]{2}{*}{ Product } & \multicolumn{4}{|c|}{ USA } & \multirow[b]{2}{*}{ Malaysia } \\
\hline & & California & Washington & Oregon & $\begin{array}{l}\text { New } \\
\text { York }\end{array}$ & \\
\hline 1 & Computers, laptops, tablets, e-readers & & Yes & & Yes & Yes \\
\hline 2 & TV & Yes & Yes & Yes & Yes & Yes \\
\hline 3 & Small Scale Servers & & & & Yes & Yes \\
\hline 4 & $\begin{array}{l}\text { Computer Peripherals1"(Keyboards, } \\
\text { mice, faxes, scanners printers }\end{array}$ & & & Yes & Yes & Yes \\
\hline 5 & $\begin{array}{l}\text { Small Electronic Equipment } \\
\text { (VCRs, DVRs, Portable Digital Music } \\
\text { Players, DVD Players, Digital } \\
\text { Converter Boxes, Cable or Satellite } \\
\text { Receivers, Electronic or Video Game } \\
\text { Consoles)" }\end{array}$ & Yes & & & Yes & \\
\hline 6 & Refrigerator, A/C, Washing machine & & & & & Yes \\
\hline 7 & Monitors & Yes & Yes & Yes & & \\
\hline & Total product categories & 3 & 3 & 3 & 5 & 5 \\
\hline
\end{tabular}

(b) The date of legislation declaration

As shown in Table 5, California is the first (2005) to declare the law on e-waste management, while the last in New York state in 2010. It is worth noting that it took 2-4 years after the date of enactment to implement the law.

(c) Recycling cost responsibility

Table 5 shows clearly that only the producer/manufacturers in California are responsible for the recycling e-waste fee. That is, the consumer pays the recycling fee at the time of product purchase. However, other states implement producerresponsibility for the recycling fee.

(iv) Landfill disposal ban
Table 5 indicates that Washington has not yet banned the disposal of e-waste totally whereas the rest of the states have banned e-waste disposal even if it is a gradual process of effecting it.

\subsubsection{Phase 2 - Comparison of models 1 and 3.}

(a) The date of legislation declaration

Table 5 indicates that Malaysia signed the e-recycle law in 2005 two years after California. However, there is a great limitation of data from Malaysia so there is no recorded date of implementation. Malaysia does not follow a laid down approach to ewaste management. Also, it is noted from Table 5 that it took 2-4 years to implement the laws after enacting them except for Malaysia. 
(b) Scope of products covered

As seen from Table 5, California started the erecycling program before Malaysia but the recycling program in Malaysia covers a wider range of products. According to Panasonic (2018), the recycling rate of air conditions, refrigerators, and washing machines is between $80 \%$ and $90 \%$ in Malaysia. These products are not covered in California.

(c) Recycling cost responsibility

California and Malaysia have different models of recycling fee responsibility as seen in Table 5. California focuses on the consumer paying for the recycling cost. Malaysia, on the other hand, shares the fee among stakeholders starting from consumers, manufacturers, and recyclers.

(d) Landfill disposal ban

Malaysia legislation has not banned the disposal of ewaste to landfill but California prohibited the disposal and it effected from 2001 (Table 5).

\subsubsection{Phase 3 - Comparison will be between models 2 and 3 .}

(a) The date of legislation declared

Table 5 shows Malaysia is the first to establish the erecycling law in 2005, but all states that signed into law after Malaysia have begun to implement the law on a specific date. While the start date of implementation of the law in Malaysia is not clear to date. In 2006, the legislation of e-recycling was declared in Washington, Oregon followed, and the last in New York in 2010.

(b) Scope of products covered
According to Table 5, most e-waste products covered by New York State, and Malaysia ranked the secondhighest in the scope of e-products covered in the recycling program. Washington and Oregon are in the middle. Only the Malaysia model covered refrigerator, $\mathrm{A} / \mathrm{C}$, washing machine.

(c) Recycling cost responsibly

Table 5 points out that Malaysia allows sharing the responsibility of the e-recycling cost, however, all electronic stakeholders should pay part of the recycling fee from consumers to recyclers. Note that other states are depending on the e-product producer to be charged for the recycling fee.

(d) Landfill disposal ban

Table 5 shows the ban on landfill disposal was progressively introduced in California recently, Oregon and New York also introduced a ban. Washington and Malaysia have not prohibited it, Most of the e-waste in Malaysia ends up in landfill (UKEssays, 2018).

(e) Total amount of e-waste collected

For Model 2 (New York, Oregon, Washington). Due to the limitation of availability of data, it was difficult to access the total e-waste collected in Malaysia in 2013, the amount is about (49752 tons) collected in New York jumped to almost a double amount is approximately (22410 tons) of the e-waste collected in 2011. Other states indicated a slow increase in ewaste amount year by year (Electronics TakeBack Coalition, 2013). The overall results of comparing the three models adopted by the 4 states in the USA and Malaysia are summarised in Table 5. 
Table 5: E-waste information of states/countries categorized into models

\begin{tabular}{|c|c|c|c|c|c|c|c|}
\hline \multirow{2}{*}{$\begin{array}{l}\text { State/ } \\
\text { Country }\end{array}$} & \multicolumn{2}{|l|}{ Recycle responsibility } & \multirow{2}{*}{$\begin{array}{l}\text { Landfill } \\
\text { disposal } \\
\text { ban }\end{array}$} & \multirow{2}{*}{$\begin{array}{l}\text { Total e- } \\
\text { waste data }\end{array}$} & \multicolumn{2}{|l|}{ Legislation } & \multirow{2}{*}{ Model } \\
\hline & Free category & Paying category & & & Year signed & $\begin{array}{l}\text { Year } \\
\text { enforced }\end{array}$ & \\
\hline $\begin{array}{l}\text { California } \\
\text { (USA) }\end{array}$ & & $\begin{array}{l}\text { The recycling fee paid by } \\
\text { consumers at the point of } \\
\text { purchase. (Namias, 2013). }\end{array}$ & Yes & available & 2003 & 2005 & $\begin{array}{l}1 \\
\text { (Not producer } \\
\text { or consumer } \\
\text { responsibility) }\end{array}$ \\
\hline $\begin{array}{l}\text { Oregon } \\
\text { (USA) }\end{array}$ & $\begin{array}{l}\text { - Households } \\
\text { - small businesses } \\
\text { - small non-profits } \\
\text { - Or anyone (even businesses) } \\
\text { dropping off } 7 \text { items or less to } \\
\text { collection points }\end{array}$ & $\begin{array}{l}\text { Producers to pay the cost of } \\
\text { recycling (collection, } \\
\text { transportation, and sorting) }\end{array}$ & Yes & available & 2007 & 2009 & $\begin{array}{l}2 \\
\text { (Producer } \\
\text { responsibility) }\end{array}$ \\
\hline $\begin{array}{l}\text { New York } \\
\text { (USA) }\end{array}$ & $\begin{array}{l}\text { - Individuals } \\
\text { - Non-profits (<75 employees) } \\
\text { - Schools } \\
\text { - Government agencies } \\
\text { - Small firms (<50 employees) } \\
\text { Large non-profits and businesses } \\
\text { may be charged". }\end{array}$ & $\begin{array}{l}\text { Producers to pay the cost of } \\
\text { recycling (collection, } \\
\text { transportation, and sorting) }\end{array}$ & Yes & Available & 2010 & 2011 & $\begin{array}{l} \\
\text { (Producer } \\
\text { responsibility) }\end{array}$ \\
\hline $\begin{array}{l}\text { Washington } \\
\text { (USA) }\end{array}$ & $\begin{array}{l}\text { "Consumers, charities, small } \\
\text { businesses, schools, and small } \\
\text { governments. }\end{array}$ & $\begin{array}{l}\text { Producers to pay the cost of } \\
\text { recycling (collection, } \\
\text { transportation, and sorting) }\end{array}$ & No & Available & 2006 & 2009 & $\begin{array}{l}2 \\
\text { (Producer } \\
\text { responsibility) }\end{array}$ \\
\hline Malaysia & $\begin{array}{l}\text { Consumers are charged a } \\
\text { recycling fee at the point of the } \\
\text { product purchase }\end{array}$ & $\begin{array}{l}\text { Manufacturers pay Extended } \\
\text { Producer Responsibility } \\
\text { (EPR) fee while recyclers } \\
\text { pay a registration fee }\end{array}$ & No & $\begin{array}{l}\text { Not } \\
\text { available }\end{array}$ & 2005 & No record & $\begin{array}{l}3 \\
\text { (Shared } \\
\text { responsibility) }\end{array}$ \\
\hline
\end{tabular}




\section{Conclusions and Recommendations}

The growing amount of e-waste is gaining increasing interest and attention on the global agenda. E-waste is a fast-growing and complex waste stream because it contains a wide range of products. This makes it extremely difficult to manage. This study analyzed and compared three international models of e-waste management currently adopted in California, Oregon, New York, Washington, and Malaysia. The volume rates of e-waste are considerably increasing because of the rapid change in technologies and the tendency of people to acquire modern devices, which generate huge quantities of electrical and electronic wastes. Lack of proper management of e-waste puts the environment at risk and threatens human health. Private companies, initiatives, and Non-ProfitOrganizations are currently working in the Kingdom of Saudi Arabia on e-waste recycling, however, the current practice requires an adequately regulated system and concrete actions. Developing a sound regulatory framework to sustainably manage e-waste is highly recommended coupled with programs to increase consumer awareness for the importance of ewaste control and management in a safe and integrated system, which will reduce the environmental and health negative impacts of ewaste.

\section{References}

Alameer, H. (2015) Integrated Framework for modelling the Management of Electronic Waste in Saudi Arabia. [Online] Available from:

http://vuir.vu.edu.au/32316/1/ALAMEER\%20Hasan \%20-\%20Thesis.pdf [Accessed May 22, 2019].

Alghazo, J. and Ouda, O. (2016) Electronic Waste management and Security in GCC Countries: A Growing Challenge. [Online] Available from: https://www.researchgate.net/publication/30953792 6_Electronic_Waste_Management_and_security_in _GCC_Countries_A_Growing_Challenge [Accessed May 22, 2019].

American Recycler News Inc. (2017) The Challenge of Legislation E-Waste Recycling. [Online]
Available from:

https://americanrecycler.com/8568759/index.php/ne ws/electronics-recycling/2385-the-challenge-oflegislating-e-waste-recycling[Accessed December 25, 2018].

Asian Region. (2014) Data Collection Survey on Ewaste Management in Malaysia and Surrounding Countries. [Online] Available from:

http://open_jicareport.jica.go.jp/pdf/12154589.pdf [Accessed March 7, 2019].

Balde, C., Forti, V., Gray, V., Kuehr, R. and Stegmann, P.(2017) The Global E-Waste Monitor 2017. [Online] Available from:

https://www.itu.int/en/ITU-D/Climate-

Change/Documents/GEM\%202017/Global-Ewaste\%20Monitor\%202017\%20.pdf [Accessed

December 16, 2018].

Basel Convention. (2011) Overview. [Online]

Available from:

http://www.basel.int/Implementation/Ewaste/Overvi ew/tabid/4063/Default.aspx [Accessed December 25, 2018].

Bergner, D. (2004) The Electronic Waste Recycling Act of 2003: California's Response to the Electronic Waste Crisis. [Online] Available from:

https://scholarship.law.marquette.edu/cgi/viewconte nt.cgi?referer=https://www.google.com/\&httpsredir $=1 \&$ article $=1023 \&$ context $=$ mulr $[$ Accessed March 5, 2019].

Button, K. (2016) 20 Staggering E-Waste Facts.

[Online] Available from: https://earth911.com/ecotech/20-e-waste-facts/ [Accessed December 25, 2018].

Dashkova, T.(2012) A Study of E-Waste Management Programs: a Comparative Analysis of Switzerland and Ontario. [Online] Available from: https://digital.library.ryerson.ca/islandora/object/RU LA:1269 [Accessed December 16, 2018].

Department of Environmental Conservation. (2017) NYS E-Waste Recycling \& Reuse Act. [Online] Available from:

https://www.dec.ny.gov/docs/materials minerals pd f/ewasterep17.pdf [Accessed March 6, 2019]. 
Department of Environmental Conservation (2019)

Electronic Waste Recycling. [Online] Available from: http://www.dec.ny.gov/chemical/65583.html [Accessed March 6, 2019].

Durkin E. (2019) Whales - Shocking autopsy photos show toll of plastic waste on dead whale. Available from:

https://www.theguardian.com/environment/2019/ma r/19/shocking-autopsy-photos-show-toll-of-plasticwaste-on-dead-whale [Accessed December 25, 2018].

EPA (2019a) Electronics Donation and Recycling. United States Environmental Protection Agency. [Online0 Available from:

https://www.epa.gov/recycle/electronics-donationand-recycling [Accessed March 20, 2019].

EPA (2019b) Is the United States a Party to the Basel Convention? United States Environmental Protection Agency [Online] Available from https://waste.zendesk.com/hc/enus/articles/212354257-Is-the-United-States-a-partyto-the-Basel-Convention- [Accessed March 20, 2019].

Edwards, L. (2016) E-Waste Recycling: The Dirty Trade between the United States and China.

[Online] Available from:

https://scholarship.claremont.edu/cgi/viewcontent.cg i?referer=https://www.google.com/\&httpsredir=1\&a $\underline{\text { rticle }=1155 \& \text { context }=\text { pomona } \_ \text {theses }}$ [Accessed

December 14, 2018].

Electronics Take Back Coalition. (2013). Brief Comparison of State Law on Electronics Recycling. Available from:

http://www.electronicstakeback.com/wpcontent/uploads/Compare_state_laws_chart.pdf

[Accessed March 10, 2019].

Forti, V., Balde, C., and Kuehr, R. (2018) E-Waste Statistics. [Online] Available from:

https://www.google.com/search?client=safari\&chan $\underline{\text { nel=ipad_bm\&source }=\text { hp\&ei=nGR2XPvCI6OMlwS }}$ xiKKoCg\&q=E-

WastE+statistics\&btnK=Google+Search\&oq=E-

WastE+statistics\&gs $1=$ psyab.3..35i3912j016j0i22i3012.2623.2623..5687...0.0..1
$.339 .728 .1 \mathrm{j} 3-2 \ldots \ldots .0 \ldots . .2 \mathrm{j} 1 .$. gws-

wiz....0.jREmef_zPuE [Accessed February 27, 2019].

Isa, H. (2012) Implementation of Basel Conventions in Malaysia. [Online] Available from

https://www.researchgate.net/publication/29382058 6_Implementation_of_Basel_Convention_in_Malay sia [Accessed on January 4, 2019].

Green Peace. (2009) Where Does E-Waste End up? [Online] Available from:

https://www.greenpeace.org/archiveinternational/en/campaigns/detox/electronics/the-ewaste-problem/where-does-e-waste-end-up/

[Accessed December 16, 2018].

Hamzah, T. Tengku. Adeline. Adura. (2011)

Making Sense of Environmental Governance: A

Study of E-waste in Malaysia, Durham theses, Durham University. [Online] Available at Durham

E-Theses Online: http://etheses.dur.ac.uk/670/

[Accessed February 28, 2019].

Lang, Gregory E. (2018) Plastics, the Marine Menace: Causes and Cures, "Florida State University Journal of Land Use and Environmental Law: Vol. 5: No. 2, Article 8. Available at:https://ir.law.fsu.edu/jluel/vol5/iss2/8 Masrom, N. (2017) New Mechanism of Household E-Waste Management in Malaysia. [Online] Available from:

https://www.env.go.jp/en/recycle/asian_net/Annual_ Workshops/2017_PDF/S3_03_Malaysia.pdf

[Accessed February 26, 2019].

Mmereki, D. Li, B. Baldwin, A. Hong, L. (2016)

The Generation, Composition, Collection,

Treatment and Disposal System, and Impact of E-

Waste. [Online] Available from:

https://www.intechopen.com/books/e-waste-intransition-from-pollution-to-resource/thegeneration-composition-collection-treatment-anddisposal-system-and-impact-of-e-waste [Accessed December 14, 2018].

Namias, J. (2013) The Future of Electronic Waste Recycling in the United States: Obstacles and Domestic Solution. [Online] Available from: http://www.seas.columbia.edu/earth/wtert/sofos/Na 
mias_Thesis_07-08-13.pdf [Accessed December 18, 2018].

NCSL. (2018) Electronic Waste Recycling. [Online] Available from:

http://www.ncsl.org/research/environment-andnatural-resources/e-waste-recycling-legislation.aspx [Accessed March 7, 2019].

Ramachandra, T. and Varghese, S. (2004)

Environmentally Sound Option for E-Waste

Management. [Online] Available from:

http://www.ces.iisc.ernet.in/energy/paper/ewaste/ew aste.html [Accessed December 16, 2018].

Richter, F. (2017) These Countries Generate the Most Electronic Waste. [Online] Available from: https://www.statista.com/chart/2283/electronicwaste/ [Accessed December 16, 2018].

Schultz,J. (2018) Electronic Waste Recycling.

[Online] Available from:

http://www.ncsl.org/research/environment-andnatural-resources/e-waste-recycling-legislation.aspx [Accessed March 6, 2019].

Semarang. (2016) Study on E-Waste Management in ASEAN Countries. [Online] Available from: https://www.env.go.jp/en/recycle/asian_net/Annual_ Workshops/2016_PDF/day1_S1_17_BCRCSEA.pdf [Accessed February 6, 2019].

Shumon, R. Ahmed, S. Islam, T. (2014) Electronic waste: Present Status and Future Perspective of Sustainable Management Practices in Malaysia.

[Online] Available from:

https://www.researchgate.net/publication/26564538

7 Electronic waste present status and future pers pectives of sustainable management practices in Malaysia [Accessed February 6, 2019].

Suja, F. Rahman, R. Yusof, A. Masdar, M. (2014)

E-Waste Management Scenarios in Malaysia.

[Online] Available from:

https://www.researchgate.net/publication/26626098 1_e-Waste_Management_Scenarios_in_Malaysia

[Accessed February 6, 2019].

Uddin, J. (2012) Journal And Conference Paper On (Environment) E-Waste Management. [Online] Available from: http://iosrjournals.org/iosr-
jmce/papers/vol2-issue1/C0212545.pdf. [Accessed December 6, 2018].

UKEssays. (2018) E-Waste Management Processes in Malaysia Environmental Sciences Essay. [Online] Available from:

https://www.ukessays.com/essays/environmentalsciences/e-waste-management-processes-inmalaysia-environmental-sciences-essay.php\#citethis [Accessed February 26, 2019]

UNESCO. (2017) Facts and figures on marine pollution. [Online] Available from

http://www.unesco.org/new/en/natural-sciences/iococeans/focus-areas/rio-20-ocean/blueprint-for-thefuture-we-want/marine-pollution/facts-and-figureson-marine-pollution/ [Accessed June 2019]

Vennila, A., Jayasiri H. B., and Pandy P.H. (2014)

Plastic debris in the coastal and marine ecosystem: a menace that needs concerted efforts. International Journal of Fisheries and Aquatic Studies 2014; 2(1): 24-29

Watson, I. (2013) Chian: The Electronic

Wastebasket of the World. [Online] Available from: https://edition.cnn.com/2013/05/30/world/asia/china -electronic-waste-e-waste/index.html [Accessed December 16, 2018].

Widmer, R., Oswald-Krapf, H., Sinha-Khetriwal, D., Scnellmann, M., Boni, H. (2005) Global Perspectives on the e-Waste. Environmental Impact Assessment Review, Vol. 25, No. 5, 2005, pp. 436458. http://dx.doi.org/10.1016/j.eiar.2005.04.001 [Accessed 15 June 2019].

Williams, P. (2018) Study Reveals Electronic Waste in New York Wasye Strea is Now Down 60 Percent. [Online] Available from:

https://www.businesswire.com/news/home/2018051 5006532/en/Study-Reveals-Electronic-Waste-NewYork-Waste [Accessed March 6, 2019].

Zainu, Z. Ali, W. Songip, A. (2015) Challenges and Innovations in Household E-waste Management in Malaysia - A Comparative Review. [Online] Available from:

https://www.academia.edu/36424764/Challenges_and_Innovati ons in Household E-waste Management in Malaysia A_Comparative_Review [Accessed February 6, 2019]. 